\title{
U.S. Relations with Southeast Asia in 2018: More Continuity Than Change
}

By David Shambaugh

\section{EXECUTIVE SUMMARY}

- The United States maintains a comprehensive and robust presence throughout Southeast Asia that has grown dramatically since the 1980s. It includes the commercial, security, education and diplomatic, and other domains. America's strengths and contributions to the region lie particularly in both hard and soft power, but the U.S. economic footprint is both broad and deep.

- However, this presence is not very well appreciated or reported by regional media - whereas China's presence and influence is pervasive. Most Southeast Asian governments are often reluctant to recognize or publicize the U.S. presence or contributions to regional security, stability, and growth.

- America's diplomatic engagement of ASEAN and the region has rightly been criticized for its episodic engagement, and Washington should substantially elevate Southeast Asia within its broader Asian and Indo-Pacific diplomatic priorities. Southeast Asia was made the highest priority ever for Washington during the Obama administration. While receding somewhat under the Trump administration, the region remains an important priority — but Washington must devote sustained attention to match the region's importance to American national interests.

- As U.S.-China competition escalates, Southeast Asia will become an epicentre of this competition. Southeast Asian states and societies may not realize the significance of the escalating U.S.-China competition for them, as most countries are internally preoccupied and buy into ASEAN's rhetoric of inclusive engagement of external powers. Southeast Asian countries are likely to become increasing 
objects of this competition, and it will be become increasingly difficult for them to ignore it.

- Meanwhile, Southeast Asian states and ASEAN must elevate their own emphasis and engagement with the United States. The U.S. brings many more strengths and benefits than does China and is a far more comprehensive actor in the region. In particular, it would be helpful if ASEAN and its member states would more publicly recognize the contributions and importance of the United States. 